Acta vet. scand. $1984,25,250-259$.

From the Department of Food Hygiene, College of Veterinary Medicine, Helsinki, Finland.

\title{
ANTIMICROBIAL RESIDUES IN MILK. COMPARISON OF DIFFERENT AGAR DIFFUSION METHODS*
}

\author{
By \\ Anna Haapoja and Hannu Korkeala
}

\begin{abstract}
HAAPOJA, ANNA and HANNU KORKEALA: Antimicrobial residues in milk. Comparison of different agar diffusion methods. Acta vet. scand. 1984, 25, 250-259. - Different agar diffusion methods were compared in order to find a sensitive method for the detection of various antimicrobial residues in milk. A total of 588 producer milk samples were analyzed using subsets of the most sensitive methods.

With the IDF method, 2 positive cases $(0.34 \%)$ appeared among the producer milk samples, with the Thermocult method 13 positive cases $(2.21 \%)$ and with the Test agar $\mathrm{pH} 8$ method with trimethoprim and glucose 4 positive cases $(0.68 \%)$. A combination of the IDF method and the Test agar $\mathrm{pH} 8$ method resulted in 6 positive cases $(1.02 \%)$ and a combination of the Thermocult method and the Test agar $\mathrm{pH} 8$ method in 17 positive cases $(2.89 \%)$. With penicillinase $41 \%$ of the positive cases were identified as $\beta$-lactam antibiotics and with paminobenzoic acid $18 \%$ of the positive cases were identified as sulphonamides. $41 \%$ of the positive cases remained unexplained.

The best combination for the detection of antimicrobial agents in milk seems to be that of the Thermocult method and the Test agar $\mathrm{pH}$ 8 method with trimethoprim and glucose.
\end{abstract}

Bacillus stearothermophilus; Bacillus subtilis; p-aminobenzoic acid; penicillinase; trimethoprim; antibiotics; sulphonamides.

Antimicrobial residues in milk are commonly detected in Finland by the method described by the International Dairy Federation (1970). This method (designated IDF method) has Bacillus stearothermophilus as a test organism. The method has been criticized for example for its insufficient sensitivity to sulphonamides (Fabiansson \& Rutegård 1979). Bacillus subtilis

* This work was partly supported by the Walter Ehrström Foundation, Helsinki, Finland. 
BGA is used in Sweden and Finland as the test organism for the detection of antimicrobial residues in slaughter animals. With this method, trimethoprim ( $\mathrm{Tr}$ ) is added to the agar in order to increase the sensitivity of the test organism to sulphonamides (Gudding 1976).

The purpose of the present study was to compare the sensitivity of methods using $B$. stearothermophilus as the test organism with the sensitivity of those methods using B. subtilis BGA, to examine the effect of the added $T r$ on the growth of the test organisms, and to analyze the occurrence of antimicrobial residues in milk with these methods.

\section{MATERIALS AND METHODS}

Antimicrobial agents

Discs preimpregnated with the following substances were used (the content per disc is given within brackets): erythromycin (78 $\mu \mathrm{g})$, penicillin (5 $\mu \mathrm{g})$, streptomycins $(100 \mu \mathrm{g})$, sulphonamides $(240 \mu \mathrm{g}$ ) and tetracyclines (oxytetracycline $80 \mu \mathrm{g}$ ) (A/S Rosco, Taastrup, Denmark).

\section{Additions of antimicrobial drugs to milk}

Dilutions of the following antibiotics were prepared with milk as the diluent: intramamm. A-mastin (ampicillin $200 \mathrm{mg}$, Orion Pharmaceutical Co., Helsinki, Finland), intramamm. Ermysin (erythromycin estolate resp. erythromycin $250 \mathrm{mg}$, Lääke, Turku, Finland) and intramamm. Terramycin (oxytetracycline hydrochloride $30 \mathrm{mg} / \mathrm{g}$, Pfizer Corporation, Brussels, Belgium). The concentrations used were $0.05,0.1,0.2,0.4,0.8$ and $1.6 \mu \mathrm{g}$ of each antibiotic per $\mathrm{ml}$ of milk.

\section{Producer milk samples}

250 milk samples from the milk control station in Helsinki and 338 milk samples from the milk control station in Loviisa, Finland, were analyzed for the detection of antimicrobial residues with different agar diffusion methods.

Agar diffusion technique

Te s t o r g a n is m s. Bacillus stearothermophilus var. calidolactis and Bacillus subtilis BGA were used. B. stearothermophilus var. calidolactis was incubated in a nutrient broth (Orion 
Diagnostica, Espoo, Finland) for $18 \mathrm{~h}$ at $55^{\circ} \mathrm{C}$, and $20 \mathrm{ml}$ of the suspension was added to $80 \mathrm{ml}$ of the medium. $0.1 \mathrm{ml}$ of $\mathrm{B}$. subtilis BGA spore suspension (E. Merck, Darmstadt, German Federal Republic) was added to $100 \mathrm{ml}$ of the medium.

Trim e th o p r i m s o l $\mathrm{t}$ i o $\mathrm{n}$. The Tr stock solution was prepared by dissolving $10 \mathrm{mg}$ of $\mathrm{Tr}$ (Sigma Chemical Co., St. Louis, Mo., USA) in $2 \mathrm{ml}$ of ethanol and adding $8 \mathrm{ml}$ of sterile distilled water (Bogaerts et al. 1981). This stock solution was diluted further with sterile distilled water.

A g a r m e d i a. B. stearothermophilus var. calidolactis was added to "Plate Count agar" (Oxoid, England), the pH of which was adjusted to 8.0 with 1-n $\mathrm{NaOH}$ (International Dairy Federation 1970). The quantity of agar per Petri dish $(\varnothing 9 \mathrm{~cm})$ was $6 \mathrm{ml}$. The IDF method, with $0.01,0.02,0.03,0.04,0.05,0.06,0.07$ and $0.15 \mu \mathrm{g}$ of $\mathrm{Tr}$ per $\mathrm{ml}$ of medium, and Thermocult plates (Orion Diagnostica), which have B. stearothermophilus var. calidolactis spore suspension as the test organism (Pekkanen \& Grünwald-Stenius 1974), were also used. B. subtilis BGA was added to the following media: “Test agar $\mathrm{pH}$ for the inhibitor test" (E. Merck, Damstadt, German Federal Republic) (denoted Test agar 6 method below), "Test agar pH 8 for the inhibitor test" (E. Merck) (denoted Test agar 8 method below) and "Test agar pH 8 for the inhibitor test" with $0.4 \%$ glucose and $0.06 \mu \mathrm{g}$ Tr per ml medium (denoted Test agar 8 method with Tr below). The addition of glucose to the media resulted in sharper inhibition zones (Nouws 1981). Ten ml of each medium was poured onto a Petri dish $(\varnothing 9 \mathrm{~cm})$.

Te s t p r o c ed u r e. Preimpregnated discs with antimicrobial drugs or filter-paper discs $(\varnothing 12.7 \mathrm{~mm}$, Schleicher \& Schüll, Dassel, German Federal Republic) with $0.1 \mathrm{ml}$ of each milk sample were placed on the media. The B. stearothermophilus var. calidolactis plates were incubated for $5 \mathrm{~h}$ at $55^{\circ} \mathrm{C}$ and the Thermocult plates for $3.5 \mathrm{~h}$ at $65^{\circ} \mathrm{C}$. With the methods using $\mathrm{B}$. subtilis BGA, the antibiotics were first allowed to diffuse from discs into the medium for a period of $1 \mathrm{~h}$ at $20^{\circ} \mathrm{C}$ (Fabiansson \& Rutegård 1979). After this prediffusion the plates were incubated for $20 \mathrm{~h}$ at $30^{\circ} \mathrm{C}$.

The zone of complete inhibition of growth was regarded as an inhibition zone. The tests on the producer milk samples with positive results were repeated as follows: with the Test agar 8 
method with Tr, a disc ( $\varnothing 6 \mathrm{~mm}$, Schleicher \& Schüll) containing $5 \mu \mathrm{g}$ p-aminobenzoic acid (PABA) (E. Merck) was placed near the sample disc, and with the IDF and Thermocult methods, a disc containing 5000 units of penicillinase (BBL, Cockeysville, Md., USA) was placed near the sample disc in order to identify residues of sulphonamides or $\beta$-lactam antibiotics (Fabiansson et al. 1981, Korkeala et al. 1982). A control disc ( $\varnothing 12.9 \mathrm{~mm}$, Schleicher \& Schüll) containing 0.01 IU penicillin per ml of milk was laid on each agar plate, the zones of the positive samples being compared with the zone of the control disc.

\section{RESULTS}

The IDF method was not sensitized to sulphonamides by adding $\operatorname{Tr}$ to the medium. Even if small concentrations of $\mathrm{Tr}$ increased the sensitivity of $B$. stearothermophilus var. calidolactis to sulphonamides, nevertheless concentrations of $0.01,0.02,0.03$ and $0.04 \mu \mathrm{g} \mathrm{Tr}$ per $\mathrm{ml}$ of agar already clearly reduced the density of the test microbe. Higher concentrations, $0.05 \mu \mathrm{g} \mathrm{Tr}$ per $\mathrm{ml}$ of medium or more, inhibited the growth of the test microbe so that the zone of inhibition could not be measured. Furthermore, even with lower concentrations of $\mathrm{Tr}$ the growth of the test microbe was so varied that the results could not be reliably interpreted.

The zones of inhibition caused by discs containing the different antimicrobial agents and using the various methods are presented in Table 1. The Test agar 8 methods yielded large zones of inhibi-

T a b l e 1 Comparison of different agar diffusion methods in sensitivity testing of antimicrobial agents.

\begin{tabular}{|c|c|c|c|c|c|c|}
\hline \multirow[b]{2}{*}{$\begin{array}{l}\text { Antimicrobial } \\
\text { agent }\end{array}$} & \multirow[b]{2}{*}{$\mu \mathrm{g} / \mathrm{disc}$} & \multicolumn{5}{|c|}{ Mean $\pm \mathrm{s}$. diameter of inhibition zones of 5 experiments $(\mathrm{mm})$ a } \\
\hline & & IDF & Thermocult & $\begin{array}{r}\text { B. subtilis BGA } \\
+ \text { Test agar pH } 6\end{array}$ & $\begin{array}{l}\text { B. subtilis BGA } \\
\text { + Test agar pH } 8\end{array}$ & $\begin{array}{l}\text { B. subtilis BGA }+ \\
\text { Test agar pH } 8 \\
+0.4 \% \text { glucose } \\
+0.06 \mu \mathrm{g} T \mathrm{Tr} / \mathrm{ml} \mathrm{b} \\
\end{array}$ \\
\hline Erythromycin & 78 & $21.4 \pm 0.30$ & $23.7 \pm 0.03$ & $31.6 \pm 0.05$ & $38.8 \pm 0.05$ & $39.7 \pm 0.10$ \\
\hline Penicillin & 5 & $35.4 \pm 0.03$ & $38.2 \pm 0.01$ & $45.5 \pm 0.17$ & $41.3 \pm 0.14$ & $41.8 \pm 0.21$ \\
\hline Streptomycin & 100 & $22.5 \pm 0.21$ & $28.3 \pm 0.05$ & $37.8 \pm 0.22$ & $47.0 \pm 0.10 \mathrm{c}$ & $47.2 \pm 0.03 c$ \\
\hline Sulphonamides & 240 & $12.9 \pm 0.11$ & $27.0 \pm 0.03$ & $44.2 \pm 0.16$ & $36.6 \pm 0.10$ & $51.9 \pm 0.06$ \\
\hline Tetracyclines & 80 & $25.6 \pm 0.09$ & $32.1 \pm 0.04$ & $44.8 \pm 0.04$ & $36.0 \pm 0.02$ & $36.4 \pm 0.07$ \\
\hline
\end{tabular}

a Diameter of disc included

b $\mathrm{Tr}=$ trimethoprim

c Single colonies inside the inhibition zone 
tion with erythromycin and streptomycin. The Test agar 8 method with $\mathrm{Tr}$ yielded a large zone of inhibition with sulphonamides. Penicillin yielded large inhibition zones with the Thermocult, the IDF and the Test agar 6 methods. The Test agar 6 method yielded large inhibition zones with tetracycline.

The zones caused by antimicrobial agents added to milk are presented in Table 2. $0.005 \mu \mathrm{g}$ ampicillin could be detected with the IDF method and the Thermocult method; the Thermocult method resulted in greater inhibition zones with different concentrations of ampicillin. The lowest concentration of erythromycin $(0.04 \mu \mathrm{g} /$ disc $)$ could be detected when the Test agar 8 method with $\mathrm{Tr}$ was used. The lowest concentration of tetracycline $(0.04 \mu \mathrm{g} /$ disc $)$ could be detected with the Thermocult method.

T a b l e 2. Zones of inhibition caused by antibiotics added to milk with different agar diffusion methods.

\begin{tabular}{|c|c|c|c|c|c|c|}
\hline \multirow[b]{2}{*}{$\begin{array}{l}\text { Antimicrobial } \\
\text { agent }\end{array}$} & \multirow[b]{2}{*}{$\mu \mathrm{g} / \mathrm{disc}$} & \multicolumn{5}{|c|}{ Mean $\pm s$. diameter of inhibition zones of 5 experiments a } \\
\hline & & IDF & Thermocult & $\begin{array}{r}\text { B. subtilis BGA } \\
+ \text { Test agar pH } 6\end{array}$ & $\begin{array}{l}\text { B. subtilis BGA } \\
+ \text { Test agar pH } 8\end{array}$ & $\begin{array}{l}\text { B. subtilis BGA+ } \\
\text { Test agar pH } 8 \\
+0.4 \text { glucose } \\
+0.06 \mu \mathrm{g} \mathrm{Tr} / \mathrm{ml} \mathrm{b}\end{array}$ \\
\hline \multirow[t]{6}{*}{ Ampicillin } & 0.005 & $21.1 \pm 1.08$ & $23.5 \pm 0.90$ & $\mathbf{0}$ & $\mathbf{0}$ & 0 \\
\hline & 0.01 & $24.0 \pm 0.99$ & $30.0 \pm 0.48$ & $\mathbf{0}$ & $\mathbf{0}$ & 0 \\
\hline & 0.02 & $25.7 \pm 0.57$ & $31.0 \pm 0.71$ & $15.4 \pm 0.80$ & $17.4 \pm 0.86$ & $17.0 \pm 1.30$ \\
\hline & 0.04 & $30.2 \pm 0.87$ & $34.9 \pm 0.62$ & $20.8 \pm 0.92 c$ & $22.1 \pm 0.49 c$ & $21.5 \pm 0.77 \mathrm{c}$ \\
\hline & 0.08 & $32.2 \pm 0.95$ & $36.6 \pm 0.78$ & $25.4 \pm 1.04 \mathrm{c}$ & $26.0 \pm 1.58 \mathrm{c}$ & $26.1 \pm 0.50 \mathrm{c}$ \\
\hline & 0.16 & $34.1 \pm 0.70$ & $37.2 \pm 1.35$ & $28.5 \pm 1.75 \mathrm{c}$ & $27.3 \pm 0.77 \mathrm{c}$ & $28.9 \pm 1.22 \mathrm{c}$ \\
\hline \multirow[t]{6}{*}{ Erythromycin } & 0.005 & 0 & 0 & 0 & 0 & 0 \\
\hline & 0.01 & 0 & 0 & 0 & 0 & 0 \\
\hline & 0.02 & 0 & 0 & 0 & 0 & 0 \\
\hline & 0.04 & 0 & 0 & 0 & 0 & $18.2 \pm 0.73$ \\
\hline & 0.08 & $17.8 \pm 0.39$ & $14.5 \pm 0.66$ & 0 & $18.5 \pm 0.30$ & $19.2 \pm 0.91$ \\
\hline & 0.16 & $18.0 \pm 0.58$ & $14.8 \pm 0.98$ & 0 & $19.0 \pm 1.12$ & $20.3 \pm 1.84$ \\
\hline \multirow[t]{6}{*}{ Tetracycline } & 0.005 & 0 & 0 & 0 & 0 & 0 \\
\hline & 0.01 & 0 & 0 & 0 & 0 & 0 \\
\hline & 0.02 & 0 & 0 & 0 & 0 & 0 \\
\hline & 0.04 & 0 & $16.4 \pm 0.91$ & 0 & 0 & 0 \\
\hline & 0.08 & 0 & $19.0 \pm 0.76$ & $15.4 \pm 0.40$ & 0 & 0 \\
\hline & 0.16 & $17.4 \pm 1.10$ & $20.4 \pm 0.45$ & $18.7 \pm 0.91$ & 0 & 0 \\
\hline
\end{tabular}

a $12.7 \mathrm{~mm}$ disc included

b $\mathrm{Tr}=$ trimethoprim

c Single colonies inside the inhibition zone 
Producer milk samples from 250 dairy farms were analyzed with the Test agar 6 method, the Test agar 8 method, the Test agar 8 method with Tr, the IDF method and the Thermocult method; producer milk samples from 338 dairy farms were analyzed with the IDF method, the Thermocult method and the Test agar 8 method with Tr. Table 3 shows the positive results of these analyses. Two positive cases $(0.34 \%)$ appeared with the IDF method, 13 positive cases $(2.21 \%)$ with the Thermocult method and 4 positive cases $(0.68 \%)$ with the Test agar 8 method with Tr. A combination of the IDF method and the Test agar 8 method with Tr resulted in 6 positive cases $(1.02 \%)$ and a combination of the Thermocult method and the Test agar 8 method with $\mathrm{Tr}$ yielded 17 positive cases $(2.89 \%)$.

T a ble 3. Zones of inhibition in producer milk samples with different agar diffusion methods.

\begin{tabular}{|c|c|c|c|c|c|}
\hline \multirow[b]{2}{*}{$\begin{array}{l}\text { ID of } \\
\text { milk } \\
\text { sample }\end{array}$} & \multicolumn{5}{|c|}{ Diameter of inhibition zone $(\mathrm{mm})$ a } \\
\hline & IDF & Thermocult & $\begin{array}{l}\text { B. subtilis BGA } \\
+ \text { Test agar pH }\end{array}$ & 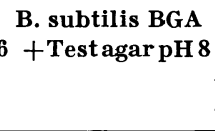 & $\begin{array}{r}\text { B. subtilis BGA } \\
+ \text { Test agar pH } 8 \\
+0.4 \% \text { glucose } \\
+0.06 \mu \mathrm{gr} / \mathrm{ml} \mathrm{b}\end{array}$ \\
\hline 38 & $24.0 \mathrm{c}$ & $26.5^{c}$ & 0 & 0 & 0 \\
\hline 95 & 0 & 16.8 & $\mathbf{0}$ & 0 & 0 \\
\hline 136 & $\mathbf{0}$ & $21.2 \mathrm{c}$ & $\mathbf{0}$ & $\mathbf{0}$ & 0 \\
\hline 172 & 0 & 16.9 & 0 & 0 & $\mathbf{0}$ \\
\hline 209 & 0 & $18.0 \mathrm{c}$ & 0 & $\mathbf{0}$ & 0 \\
\hline 216 & 0 & 17.0 & 0 & $\mathbf{0}$ & $\mathbf{0}$ \\
\hline 233 & 0 & $\mathbf{1 7 . 5}$ & $\mathbf{0}$ & 0 & 0 \\
\hline 248 & $\mathbf{0}$ & $\mathbf{0}$ & $\mathbf{0}$ & 0 & $18.5^{d}$ \\
\hline 290 & $20.8 \mathrm{c}$ & $22.0 \mathrm{c}$ & NDe & ND & 0 \\
\hline 315 & 0 & 0 & ND & ND & $30.0 \mathrm{~d}$ \\
\hline 333 & 0 & $18.0 \mathrm{c}$ & ND & ND & 0 \\
\hline 391 & 0 & 20.5 & ND & ND & 0 \\
\hline 396 & 0 & $18.9 \mathrm{c}$ & ND & ND & 0 \\
\hline 399 & 0 & 17.2 & ND & ND & 0 \\
\hline 449 & 0 & 0 & ND & ND & $25.1^{d}$ \\
\hline 513 & 0 & 18.3 & ND & ND & 0 \\
\hline 574 & 0 & 0 & ND & ND & $21.4^{f}$ \\
\hline
\end{tabular}

a $12.7 \mathrm{~mm}$ disc included

b $\mathrm{Tr}=$ trimethoprim

c Inhibition zone reduced by the penicillinase disc

d Inhibition zone reduced by the PABA disc

e Not determined

f Single colonies inside inhibition zone 
Under Finnish regulations, milk which gives an inhibition zone exceeding the inhibition zone of $0.01 \mathrm{IU}$ penicillin per $\mathrm{ml}$ of milk examined with either of the two officially approved methods in Finland, the IDF method or the Thermocult method, is considered unfit for human consumption (Anon. 1975). Results (Table 3) which had an inhibition zone larger than 0.01 IU penicillin per ml milk consisted of 1 case or $0.17 \%$ with the IDF method (sample No. 38) and 2 cases or $0.34 \%$ with the Thermocult method (samples Nos. 38 and 290). The share is slightly higher than $0.07 \%$, which was the extent of positive results in Finland in 1982 (222 positive results out of a total of 318,060 samples) (Anon. 1983).

The penicillinase disc reduced the zones of inhibition in 7 samples and the PABA discs in 3 samples (Table 3). $\beta$-lactam antibiotics included $41 \%$ and sulphonamides $18 \%$ of the producer milk samples with zones of inhibition.

In addition, inhibition zones $<1.8 \mathrm{~mm}$ appeared in 48 samples with the IDF and the Thermocult methods. The zones were excluded from Table 3 because of their small size. The zones did not disappear when the milk samples were kept at $4^{\circ} \mathrm{C}$ and the tests repeated after 24 and $48 \mathrm{~h}$. Penicillinase had no effect on the zones.

\section{DISCUSSION}

According to the results of the present study, B. stearothermophilus var. calidolactis is not sensitized to sulphonamides with added Tr. In order to detect sulphonamides in milk, other methods are required. Fabiansson \& Rutegård (1979) also showed that the addition of Tr may result in complete inhibition of the growth of B. stearothermophilus.

According to the results shown in Tables 1 and 2, antimicrobial agents of various kinds are more often detected with the Thermocult method than with the IDF method. Especially with sulphonamides, but also with erythromycin and streptomycin the Test agar 8 method with $\mathrm{Tr}$ was clearly more sensitive than the IDF and the Thermocult methods. It was surprising that the Thermocult method could detect lower tetracycline concentrations added to milk than the Test agar 6 method, although the tetracycline disc $(80 \mu \mathrm{g}$ oxytetracycline/disc) caused a greater inhibition zone with the Test agar 6 method than with the Thermocult method. The lack of prediffusion in the Thermocult method may 
have the effect that when large concentrations of tetracycline are used, antimicrobial agents are not absorbed fast enough and the critical concentration is reached nearer the disc than with the Test agar 6 method with $1 \mathrm{~h}$ prediffusion time (Barry 1980). It is probably not a question of a chelating action between tetracycline and the calcium ions of milk, since high concentrations of tetracycline added to milk had a larger inhibition zone with the Test agar 6 method than with the Thermocult method. The IDF method and the Thermocult method were highly sensitive to penicillin and ampicillin.

The results of the analysis of the producer milk samples confirmed that using two different methods results in a higher proportion of positive samples (Table 3 ). The same result has also been reported in studies concerning antimicrobial residues in meat (Korkeala et al. 1983). $\beta$-lactam antibiotics and sulphonamides included $59 \%$ of the samples with antimicrobial agents. Since oxytetracycline is widely used in veterinary practice in Finland (Jahkola 1983), and the Thermocult method reveals small amounts of the drug (Table 2), oxytetracycline may form a considerable proportion of the $41 \%$ of positive results which remained unexplained. Of those positive producer milk samples which were observed with the Test agar 8 method with $\mathrm{Tr}, 3$ were obviously caused by sulphonamides and 1 was caused by some other antimicrobial agent. In 1 positive case where the inhibition zone was reduced by $\mathrm{PABA}$, the farmer reported that 1 cow had been treated orally with drugs containing sulphonamides.

Inhibitory substances are produced in raw milk when the $\mathrm{pH}$ decreases to 6.3 and below (Duthie et al. 1976, Pekkanen \& Soback 1977). These substances inhibit the growth of $B$. subtilis and Micrococcus luteus (Duthie et al. 1976) and were also found with the IDF and the Thermocult methods (Pekkanen \& Soback 1977). In this study very small inhibition zones were found with the IDF and the Thermocult methods but not with the methods using B. subtilis BGA. The IDF method and the Thermocult method are sensitive to penicillin, but penicillinase had no effect on these zones. It is possible that some of the small zones of inhibition with the Thermocult method which were excluded from Table 3 were caused by tetracycline, while the rest of the zones with the IDF and the Thermocult methods might be caused by other inhibitory substances, as for example lysozyme (Goudswaard et al. 1978), in the milk. 
On the basis of these findings, the best combination for the detection of antimicrobial agents in milk seems to be the Thermocult method and the Test agar 8 method with Tr. A disadvantage of the B. subtilis BGA method is the long incubation period compared to the method using $B$. stearothermophilus. When only B. stearothermophilus is used as a test organism, the result is available the same day, whereas when $B$. subtilis BGA is used the result is only available the following day.

\section{REFERENCES}

Anon.: Maa- ja metsätalousministeriön päätös maitonäytteistä. (The decision of the Ministry of Agriculture and Forestry concerning milk samples). 1975, No. 453.

Anon.: Maitohygienialiitto 1982. (Association for Milk Hygiene 1982). Maitohygienialiitto, Helsinki 1983, 15 pp.

Barry, A. L.: Procedures for testing antibiotics in agar media: theoretical considerations. In V. Lorian, ed.: Antibiotics in Laboratory Medicine. Williams \& Wilkins, Baltimore, USA 1980, p. $1-23$.

Bogaerts, R., J. M. de Groodt \& D. de Vos: An ultra-sensitive microbiological method for the semi-quantitative detection of lowlevel sulfonamides. J. Food Sci. 1981, 46, 158-160.

Duthie, A. H., C. G. Woelfel, K. M. Nilson \& H. V. Atherton: Heatsensitive inhibitor(s) produced in poor quality raw milk. J. Milk Food Technol. 1976, 39, 774-775.

Fabiansson, S., C. Kihlberg, A. Rutegård \& I. Anderson: Identifiering av kemoterapeutika $i$ slaktkroppar. (Identification of antimicrobial drugs in slaughter animals). Svensk Vet.-Tidn. 1981, 33, 7-10.

Goudswaard, J., E. C. Bakkker-de Koff \& H. P. M. van RavenswaaijKraan: Lysozyme and its presence in bovine milk and serum. Tijdschr. Diergeneesk. 1978, 103, 445-450.

Gudding, R.: An improved bacteriological method for the detection of sulfonamide residues in food. Acta vet. scand. 1976, 17, 458-464.

International Dairy Federation: Detection of penicillin in milk by disc assay technique. 1970, Int. Stand. FIL-IDF 57, 7 pp.

Jahkola, M.: Mitä lääkärit odottavat eläinlääkärien antibioottien käytöltä. (What do the physicians expect for the veterinary use of antibiotics). In: Proceedings of Veterinary Conference, Finnish Veterinary Association, Helsinki 1983, 259—267.

Korkeala, H., O. Sorvettula, O. Mäki-Petäys \& J. Hirn: Comparison of different agar diffusion methods for the detection of antimicrobial residues in slaughter animals. Acta vet. scand. 1982, 23, $407-415$. 
Korkeala, H., O. Sorvettula, O. Mäki-Petäys \& J. Hirn: Comparison of different agar diffusion methods for the detection of residues in the kidneys of pigs treated with antimicrobial drugs. Meat Science 1983, 9, 291-304.

Nouws, J. F. M.: Microbiological assay methods for sulfonamides in animals tissues, serum and milk. Vet. Quart 1981, 3, 136-142.

Pekkanen, T. J. \& V. Grünwald-Stenius: Thermocult-pikamenetelmä antibioottisten ja kemoterapeuttisten aineiden osoittamiseksi maidosta. (Thermocult, quick method for detection of antibiotics and chemoterapeutic substances in milk). Suom. EläinlääkLehti 1974, 80, 205-211.

Pekkanen, T. J. \& S. Soback: Heat stable inhibitors produced in raw milk. Nord. Vet.-Med. 1977, 29, 436—439.

\section{SAMMANFATTNING}

Antimikrobiella rester $i$ mjölk. Jämförelse mellan olika agar-diffusions metoder.

I undersökningen jämfördes olika agar-diffusions metoder för att finna en sensitiv metod för att upptäcka olika antimikrobiella rester i mjölk. 588 prover av producentmjölk analyserades med de mest sensitiva metoderna.

I proverna på producentmjölk upptäcktes 2 positiva fall $(0.34 \%)$ med IDF-metoden, 13 positiva fall $(2.21 \%)$ med Thermocult-metoden och 4 positiva fall $(0.68 \%)$ med Test agar $\mathrm{pH}$ 8-metoden med trimetoprim- och glucos-tillsatser. En kombination av IDF-metoden och Test agar $\mathrm{pH}$ 8-metoden resulterade i 6 positiva fall $(1.02 \%)$ och en annan kombination av Thermocult-metoden och Test agar $\mathrm{pH}$ 8-metoden resulterade i 17 positiva fall $(2.89 \%)$. Med penicillinas blev $41 \%$ av de positiva fallen identifierade som $\beta$-lactam antibioter och med paminobenzoicsyra kunde $18 \%$ av de positiva fallen påvisas vara sulfonamider. $41 \%$ av de positiva fallen förblev oidentifierade.

Den bästa kombinationen för att upptäcka antimikrobiella rester i mjölk värkade vara en kombination av Thermocult-metoden och Test agar pH 8-metoden med trimetoprim- och glukos tillsatser.

(Received March 16, 1984).

Reprints may be requested from: Hannu Korkeala, the Department of Food Hygiene, College of Veterinary Medicine, P. O. Box 6, SF-00551 Helsinki 55, Finland. 